\title{
Optomagnetic detection of DNA triplex nanoswitches
}

\author{
Minero, Gabriel Khose Antonio; Fock, Jeppe; McCaskill, John S; Hansen, Mikkel Fougt
}

Published in:

The Analyst

Link to article, DOI:

10.1039/c6an02419j

Publication date:

2017

Document Version

Peer reviewed version

Link back to DTU Orbit

Citation (APA):

Minero, G. K. A., Fock, J., McCaskill, J. S., \& Hansen, M. F. (2017). Optomagnetic detection of DNA triplex nanoswitches. The Analyst, 142(4), 582-585. https://doi.org/10.1039/c6an02419j

\section{General rights}

Copyright and moral rights for the publications made accessible in the public portal are retained by the authors and/or other copyright owners and it is a condition of accessing publications that users recognise and abide by the legal requirements associated with these rights.

- Users may download and print one copy of any publication from the public portal for the purpose of private study or research.

- You may not further distribute the material or use it for any profit-making activity or commercial gain

- You may freely distribute the URL identifying the publication in the public portal

If you believe that this document breaches copyright please contact us providing details, and we will remove access to the work immediately and investigate your claim. 


\title{
Optomagnetic detection of DNA triplex nanoswitches'
}

\author{
Gabriel Antonio S. Minero, ${ }^{\mathrm{a}, \mathrm{b}}$ Jeppe Fock, ${ }^{\mathrm{a}}$ John S. McCaskill, ${ }^{\mathrm{b}}$ and Mikkel F. Hansen ${ }^{\mathrm{a} \dagger}$
}

We report on optomagnetic dose-dependent detection of DNA triplex-mediated and $\mathrm{pH}$-switchable clusters of functionalised magnetic nanoparticles.

Polypurine-polypyrimidine sequences can fold into triple helical DNA structures forming T-A-T and C-G-C ${ }^{+}$ nucleobase triplets upon protonation of cytosine bases at $\mathrm{pH} \leq 6{ }^{1}$ The predictable and $\mathrm{pH}$-controlled base pairing makes triplex-forming sequences very useful for programming chemical reactions, ${ }^{2,3}$ nanomachines, ${ }^{4,5}$ nanostructures, ${ }^{6-8}$ and hydro-gels. ${ }^{9,10}$ Switching of $\mathrm{pH}$ responsive DNA composites can be employed for controlled release of targets in delivery systems ${ }^{11,12}$ and in on/off regulation of the nanoscale devices upon cyclic alternation of $\mathrm{pH}$ values. ${ }^{13}$

Further, triplex-forming sequences of DNA are known to play a significant role in genetic regulation. ${ }^{14-17}$ Conditions favouring triplex binding can be screened using fluorescent molecular probes ${ }^{18,19}$ or by DNA mobility shift assays. ${ }^{17}$ For the latter, the assay time can be reduced to $10-15$ min using capillary gel electrophoresis., ${ }^{3,9}$ Palindromic homopurine-homopyrimidine tracts have been shown to cause a $\mathrm{pH}$ dependent structural transition of a plasmid DNA in vivo and have been observed during the initial replication of tumor viruses. ${ }^{20}$ Therefore, dosedependent detection of polypurine tracts (PPT) in human and viral genomes can contribute to molecular diagnostics of genetic biomarkers such as the conserved PPT region of HIV-1. ${ }^{21}$

Label-free detection of DNA targets has been demonstrated with high selectivity and sensitivities in the $0.05-10 \mathrm{nM}$ range using electrochemical biosensors. ${ }^{22}$ Multi-step DNA processing has further decreased sensitivities to the sub-pM range. ${ }^{23,24}$ Electrochemical detection of triplex DNA formation of double-stranded DNA targets with DNA probes on an electrode surface has been demonstrated directly in complex sample matrices, such as blood serum, with a limit of detection (LOD) of about $10 \mathrm{nM} .^{21}$ Analysis of triplex formation of a PPT target as short as 10 bases was demonstrated down to $\mathrm{nM}$ concentrations. ${ }^{25}$

Nanoscale optical DNA sensing was examined using confocal microscopy of light-emitting nanowires functionalised with $p$-DNA resulting in an LOD of $100 \mathrm{aM}^{26}$ Colorimetric detection of DNA based on agglutination of gold nanoparticle (NP) was reported for target DNA concentrations of $75 \mathrm{nM}^{27} 150 \mathrm{nM}^{28}$ and $3.3 \mu \mathrm{M} .^{29}$ The LOD could be reduced to $0.1 \mathrm{pM}$ via dark field microscopy imaging. ${ }^{27}$ The duplex DNAinduced NP aggregation required $2 \mathrm{~h}$ of incubation. For triplex DNA hybridisation prolonged incubation times of $12 \mathrm{~h}$ and $24 \mathrm{~h}$ were needed. ${ }^{29,30}$

Magnetic nanoparticles (MNPs) are increasingly being used for robust solid phase analyte detection, ${ }^{31-33}$ and for delivery of small molecules. ${ }^{34-36}$ Recently, an optomagnetic method to detect agglutination of MNPs was proposed and used to detect DNA from different pathogenic bacteria after rolling circle amplification ${ }^{33}$ as well as to investigate the $\mathrm{Cu}^{2+}$ binding properties of metformin. ${ }^{32}$ The method measures the modulation of laser light transmitted through the sample container in response to an applied oscillating magnetic field. This modulation arises from the coupled magnetic and optical anisotropies of the MNPs and is highly sensitive to size-changes of the MNPs due to agglutination. ${ }^{33}$

Here, we employ the optomagnetic readout principle (Fig. 1A) to investigate reversible triplex DNA formation (Fig. 1B). A single population of MNPs is functionalised with palindromic polypyrimidine DNA oligonucleotides. At $\mathrm{pH} \leq 6$, a triplex structure will form between two palindromic polypyrimidine DNA strands situated on separate MNPs and a polypurine target DNA in suspension. Thus, the presence of the target DNA 
causes formation of MNP clusters at $\mathrm{pH} \leq 6$. The kinetics of cluster formation is accelerated by application of a strong magnetic field (magnetic incubation). We show that the magnetic incubation combined with the optomagnetic readout reduces the assay time to a few minutes (Section S3+).

Two previously presented setups were used: the first setup was adapted for a cuvette ${ }^{37}$ (Fig. 1A), where $\mathrm{pH}$ titration was easy to handle; the second setup included a fully automated lab-on-a-disc sample handling including sequential magnetic incubation and readout of up to 18 sample pools. $^{33}$ In brief, a sinusoidally varying external magnetic field modulates the transmission of monochromatic light $(\lambda=405 \mathrm{~nm})$ as the MNPs cyclically relax away from and align towards the magnetic field direction. The real and imaginary components $V_{2}^{\prime}$ and $V_{2}^{\prime \prime}$ of the $2^{\text {nd }}$ harmonic signal are normalised with the average signal, $V_{0}$, to account for variations in the incoming light intensity. More information about the optomagnetic method can be found in Section S1t. Experiments involving switching of triplex DNA were carried out in the cuvette setup.
A
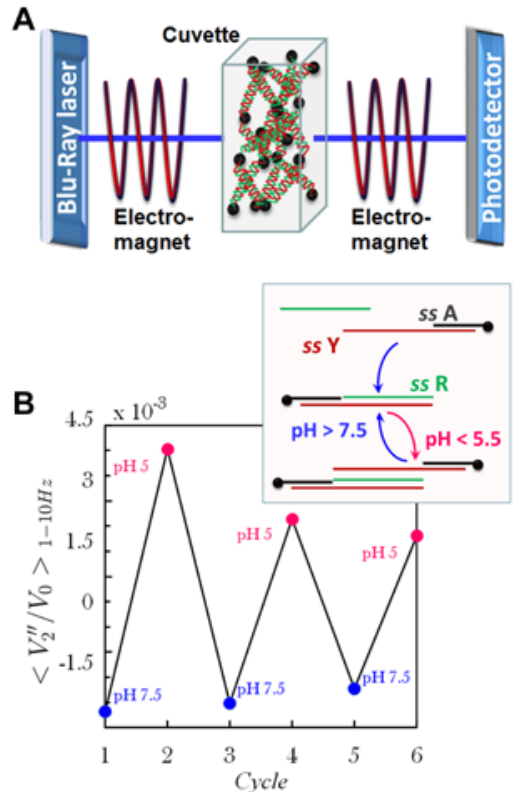

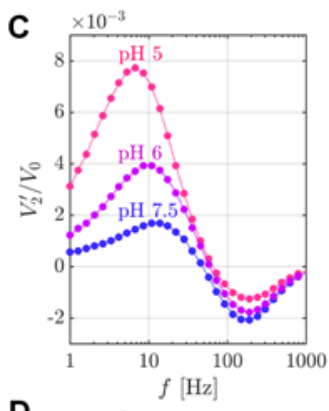

D

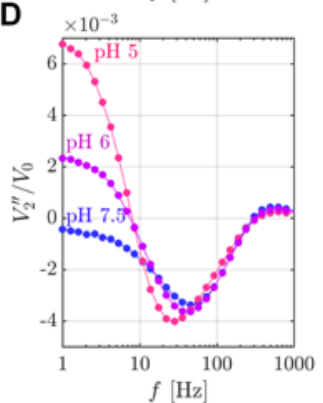

Fig. 1: $\mathrm{pH}$-dependent optomagnetic detection of triplex DNA nanoswitches. (A) Setup for optomagnetic monitoring of MNP agglutination. ${ }^{37}$ (B) Optomagnetic detection of $\mathrm{pH}$ nanoswitches; DNA sequences are listed in Table S1†. (C-D). Triplex DNA processing at $\mathrm{pH} 7.5,6.0$, and 5.0 for $0.2 \mathrm{mg} / \mathrm{ml}$ MNPs (at intermediate probe density, 50 p-DNA per MNP) in the presence of $1 \mathrm{nM}$ target ss DNA. (C) $V_{2}^{\prime} / V_{0}$ and (D) $V_{2}^{\prime \prime} / V_{0}$ vs frequency. Magnetic incubation of the mixed samples for $2 \mathrm{~min}$ in $20 \mathrm{mT}$ magnetic field was used to accelerate DNA-mediated agglutination. More information about the probe density is given in Fig. S1†.

As a proof of principle, we first measured the $\mathrm{pH}$ dependence of the system response at three $\mathrm{pH}$ values (Fig. 1C-D). The obtained optomagnetic spectra can be divided into two regions; one above $50 \mathrm{~Hz}$ and one below $50 \mathrm{~Hz}$. In $V_{2}^{\prime} / V_{0}$ (Fig. 1C), the negative peak above $50 \mathrm{~Hz}$ corresponds to free MNPs. ${ }^{37,38}$ Below $50 \mathrm{~Hz}$, a positive peak in $V_{2}^{\prime} / V_{0}$ is observed, which arises from clusters with a circumference larger than the wavelength. The sign change is due to a change in the scattering properties of the larger particles. ${ }^{37}$ In $V_{2}^{\prime \prime} / V_{0}$ (Fig. 1D), the signal below $50 \mathrm{~Hz}$ is composed of a negative contribution to the signal from free MNPs and positive contributions from MNP clusters.

For $\mathrm{pH}$ decreasing from 7.5 to 5.0, we observed a decrease in the negative $V_{2}^{\prime} / V_{0}$ peak at about $200 \mathrm{~Hz}$ in Fig. 1C (depletion of free MNPs) and, correspondingly, an increase in the positive signal at $f<50 \mathrm{~Hz}$ (formation of clusters). Both effects contribute to an increasing signal in $V_{2}^{\prime \prime} / V_{0}$ below $10 \mathrm{~Hz}$ in Fig 1D. Without magnetic incubation, however, the spectra were almost identical to that of the no-target sample (Fig. S2 + ). For further analysis, we used the average signal $\left\langle V_{2}^{\prime \prime} / V_{0}\right\rangle_{1-10 \mathrm{~Hz}}$ at $f=1-10 \mathrm{~Hz}$, as this provided the largest response to the cluster formation. The obtained $\mathrm{pH}$-dependence of the optomagnetic signal was consistent with our studies of the triplex switching reported previously. ${ }^{3}$ The nanoswitches between stable $(\mathrm{pH}<5.5)$ and unstable $(\mathrm{pH}>7.5)$ conditions for triplex formation were observed to behave reversibly and to be clearly detectable in the optomagnetic signal (Fig. 1B). We also investigated real-time detection of melting DNA bridges between MNPs and the resulting depletion of MNP clusters at low pH (Fig. S3†). The obtained trends of optomagnetic signal vs. temperature were consistent with melting of the triplex DNA (broad melting transition at $45-55^{\circ} \mathrm{C}$ ). ${ }^{3}$ 
Below, all optomagnetic signals were measured after automated magnetic incubation on a disc. ${ }^{33}$ The presence of matching DNA target (0.1-2 nM) revealed clustering of MNPs via formation of triplex DNA $Y \bullet R \bullet Y$ at conditions favourable for triplex formation $(\mathrm{pH} 5.0)$ (Fig. 2A). These were seen in the low-frequency response as discussed in the previous section and in Section S5t. The specificity of the triplex formation was investigated using a non-matching DNA for which no detectable changes in $V_{2}^{\prime \prime}$ were observed (Fig. S4†).
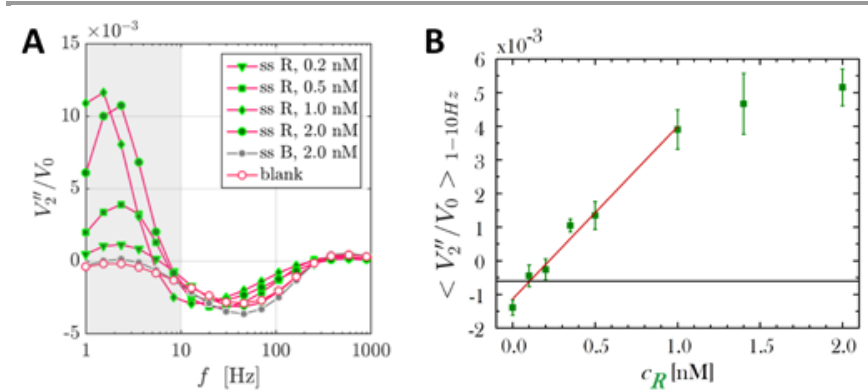

Fig. 2: Dose-dependent analysis of optomagnetic signal from the MNPs/p-DNA in the presence of matching target DNA. (A) Optomagnetic spectra from the sequence specific $Y \bullet R \bullet Y$ at $\mathrm{pH}$ 5.0. (B) $\left\langle V_{2}^{\prime \prime} / V_{0}\right\rangle_{1-10 \mathrm{~Hz}}$ vs. concentration of polypurine target DNA. The black line represents the LOD obtained as the signal from the no-target sample plus three times its standard deviation. See Section $\mathrm{S}^{+}+$for more details on the assay.

It is well known that the gain of DNA sensors is a complex function of the capture probe packing density. ${ }^{22,39}$ For the MNP concentration of $0.2 \mathrm{mg} / \mathrm{ml}$, we observed the most sensitive detection of target at intermediate packing density (50 p-DNA probes per MNP), see Fig. S5t.

Electrochemical biosensors have been applied for labelfree detection of DNA targets at sub-pM concentrations, but they require several fabrication steps (4-5 steps $^{22,23}$ taking more than $24 \mathrm{~h}$ ), external stimuli for amplification of the signal, e.g., via conformational changes of DNA probes on the electrode surface and are also sensitive to the liquid properties. The presented MNP-based readout has the advantages that a sensitive detection scheme can be applied for any liquid suspension of the MNPs and that the magnetic incubation reduces the assay time to a few minutes compared to for example $12 \mathrm{~h}$, which has been reported for the assembly of gold nanoparticles. ${ }^{30}$

In conclusion, we have demonstrated optomagnetic detection of 0.1-2 nM polypurine target DNA via triplex folding in the presence of magnetic nanoparticles with complementary palindromic DNA probes attached to the surface. The strong signal at low frequencies solely observed in the presence of the matching target and for $\mathrm{pH} 5$, indicates agglutination of the MNPs via triplex formation. The obtained MNP clusters can be switched by $\mathrm{pH}$, with a reaction time reduced to less than $10 \mathrm{~min}$ using magnetic incubation. Although our approach is limited to homopurine or homopyrimidine triplexforming sequences, it can be extended to non-palindromic target and probes by introducing a second population of functionalised MNPs according to $\mathbf{Y}_{1} \bullet \mathbf{R} \bullet \mathbf{Y}_{2}$. Targets can be identified as polypurine subsequences of 16-20 bases, which are commonly found in human and pathogen genomes. ${ }^{25}$ Moreover, the recognition length of PPTs can even be reduced to $10 \mathrm{nt}$ by introducing synthetic modifications in the probes. $^{40}$ With this in mind, the approach can be extended to be compatible with physiological conditions $(\mathrm{pH} \sim 7){ }^{41}$

We would like to thank Giovanni Rizzi for help with real-time melting curve measurements and Marco Donolato for helpful discussions. This work was supported by FP7 projects ECCell (\#222422), MATCHIT (\#249032), and NanoMag (\#604448), and DFF project (\#4184-00121B).

\section{Notes and references}

G. E. Plum, D. S. Pilch, S. F. Singleton and K. J. Breslauer, Annu. Rev. Biophys. Biomol. Struct., 1995, 24, 319-350. Y. Chen and C. Mao, J. Am. Chem. Soc., 2004, 126, 1324013241.

G. A. S. Minero, P. F. Wagler, A. a. Oughli and J. S. McCaskill, RSC Adv., 2015, 5, 27313-27325. D. Liu and S. Balasubramanian, Angew. Chemie - Int. Ed., 2003, 42, 5734-5736.

5 Y. Chen, S. H. Lee and C. Mao, Angew. Chemie - Int. Ed., 2004, 43, 5335-5338.

6 Y. Kawabata, T. Ooya, W. K. Lee and N. Yui, Macromol. Biosci., 2002, 2, 195-198.

7 Y. Chen, H. Liu, T. Ye, J. Kim and C. Mao, J. Am. Chem. Soc., 2007, 129, 8696-8697. 

ACS Nano, 2012, 6, 3604-3613. P. Wagler, G. A. S. Minero, U. Tangen, J. W. De Vries, D. Prusty, M. Kwak, A. Herrmann and J. S. Mccaskill, Electrophoresis, 2015, 35, 2451. W. Guo, C. Lu, R. Orbach, F. Wang, X. Qi, A. Cecconello, D. Seliktar and I. Willner, Adv. Mater., 2015, 73-78. C. Sun, J. S. H. Lee and M. Zhang, Adv. Drug Deliv. Rev., 2008, 60, 1252-1265.

12 V. V. Mody, A. Cox, S. Shah, A. Singh, W. Bevins and H. Parihar, Appl. Nanosci., 2013, 4, 385-392.

13 K. Haruna, H. lida, K. Tanabe and S. Nishimoto, Org. Biomol. Chem., 2008, 6, 1613-1617. N. Baran, A. Lapidot and H. Manor, Proc. Natl. Acad. Sci. U. S. A., 1991, 88, 507-511. A. Dayn, G. M. Samadashwily and S. M. Mirkin, Proc. Natl. Acad. Sci. U. S. A., 1992, 89, 11406-11410. G. M. Samadashwily, A. Dayn and S. M. Mirkin, EMBO J., 1993, 12, 4975-4983.

17 L. D. Nelson, C. Bender, H. Mannsperger, D. Buergy, P. Kambakamba, G. Mudduluru, U. Korf, D. Hughes, M. W. Van Dyke and H. Allgayer, Mol. Cancer, 2012, 11, 38. K.-C. Lin, C.-Y. Kuo, C.-C. Nieh and W.-L. Tseng, RSC Adv., 2014, 4, 38389-38392. A. Idili, A. Vallée-Bélisle and F. Ricci, J. Am. Chem. Soc., 2014, 136, 5836-5839. V. Kopel, A. Pozner, N. Baran and H. Manor, Nucleic Acids Res., 1996, 24, 330-335. A. Patterson, F. Caprio, A. Vallee-Belisle, D. Moscone, K. W. Plaxco, G. Palleschi and F. Ricci, Anal. Chem., 2010, 82, 9109-9115. X. Wang, A. Jiang, T. Hou and F. Li, Anal. Chim. Acta, 2015, 890, 91-97. M. Xu, J. Zhuang, X. Chen, G. Chen and D. Tang, Chem. Commun. (Camb)., 2013, 49, 7304-6. Q. Wang, F. Gao, J. Ni, X. Liao, X. Zhang and Z. Lin, Sci. Rep., 2016, 6, 22441. A. Idili, A. Amodio, M. Vidonis, J. Feinberg-Somerson, M. Castronovo and F. Ricci, Anal. Chem., 2014, 86, 9013-9019. D. H. Park, N. Kim, C. Cui, Y. K. Hong, M. S. Kim, D.-H. Yang, D.-C. Kim, H. Lee, J. Kim, D. J. Ahn and J. Joo, Chem. Commun. (Camb)., 2011, 47, 7944-6. T. Bu, T. Zako, M. Fujita and M. Maeda, Chem. Commun. (Camb)., 2013, 49, 7531-3. M. S. Han, A. K. R. Lytton-Jean and C. A. Mirkin, J. Am Chem. Soc., 2006, 128, 4954-4955. X. Zhu, Y. Liu, J. Yang, Z. Liang and G. Li, Biosens. Bioelectron., 2010, 25, 2135-2139. H. Yan, C. Xiong, H. Yuan, Z. Zeng and L. Ling, J. Phys. Chem. C, 2009, 113, 17326-17331. H. Yin, H. Kuang, L. Liu, L. Xu, W. Ma, L. Wang and C. Xu, ACS Appl. Mater. Interfaces, 2014, 6, 4752-4757. X. Quan, R. Uddin, A. Heiskanen, M. Parmvi, K. Nilson, M. Donolato, M. F. Hansen, G. Rena and A. Boisen, Chem. Commun., 2015, 51, 17313-17316.

Nano, 2015, 9, 7374-7382.

T. M. Allen and P. R. Cullis, Science, 2004, 303, 1818-1822.

Y. H. Jung, K. B. Lee, Y. G. Kim and I. S. Choi, Angew. Chemie - Int. Ed., 2006, 45, 5960-5963.

C. Zhao, K. Qu, J. Ren and X. Qu, Chemistry, 2011, 1-8. M. Donolato, P. Antunes, R. S. Bejhed, T. Zardán Gómez de la Torre, F. W. Østerberg, M. Strömberg, M. Nilsson, M. Strømme, P. Svedlindh, M. F. Hansen and P. Vavassori, Anal. Chem., 2015, 87, 1622-1629.

J. Fock, M. Parmvi, M. Strömberg, P. Svedlindh, M. Donolato and M. F. Hansen, Biosens. Bioelectron., 2017, 88, 94-100.

K. B. Cederquist and C. D. Keating, Langmuir, 2010, 26, 18273-18280.

K. R. Fox and T. Brown, Biochem. Soc. Trans., 2011, 39, 629-634.

D. A. Rusling, L. Le Strat, V. E. C. Powers, V. J. BroughtonHead, J. Booth, O. Lack, T. Brown and K. R. Fox, FEBS Lett., 2005, 579, 6616-6620. 